\title{
The Triad Mother-Breast Milk-Infant as Predictor of Future Health: A Narrative Review
}

\author{
Elvira Verduci ${ }^{1,2,+(\mathbb{D}}$, Maria Lorella Gianni ${ }^{3,4, *,+}+\mathbb{D}$, Giulia Vizzari ${ }^{3}$, Sara Vizzuso ${ }^{2}$ (D) Jacopo Cerasani $^{3}$ (D), \\ Fabio Mosca ${ }^{3,4}$ and Gian Vincenzo Zuccotti ${ }^{2}$ (D)
}

1 Department of Health Sciences, University of Milan, 20154 Milan, Italy; elvira.verduci@unimi.it

2 Department of Pediatrics, Vittore Buzzi Children's Hospital University of Milan, 20154 Milan, Italy; sara.vizzuso@unimi.it (S.V.); gianvincenzo.zuccotti@unimi.it (G.V.Z.)

3 Department of Clinical Sciences and Community Health, University of Milan, Via San Barnaba 8, 20122 Milan, Italy; giulia.vizzari@unimi.it (G.V.); jacopo.cerasani@unimi.it (J.C.); fabio.mosca@unimi.it (F.M.)

4 Fondazione IRCCS Ca' Granda Ospedale Maggiore Policlinico NICU, Via Commenda 12, 20122 Milan, Italy

* Correspondence: maria.gianni@unimi.it

+ These authors have contributed equally to this work.

Citation: Verduci, E.; Giannì, M.L.; Vizzari, G.; Vizzuso, S.; Cerasani, J.; Mosca, F.; Zuccotti, G.V. The Triad Mother-Breast Milk-Infant as Predictor of Future Health: A Narrative Review. Nutrients 2021, 13, 486. https://doi.org/10.3390/ nu13020486

Academic Editor: Nadja Haiden Received: 31 December 2020

Accepted: 29 January 2021

Published: 2 February 2021

Publisher's Note: MDPI stays neutral with regard to jurisdictional claims in published maps and institutional affiliations.

Copyright: (c) 2021 by the authors. Licensee MDPI, Basel, Switzerland. This article is an open access article distributed under the terms and conditions of the Creative Commons Attribution (CC BY) license (https:// creativecommons.org/licenses/by/ $4.0 /)$.

\begin{abstract}
The benefits of human milk for both mother and infant are widely acknowledged. Human milk could represent a link between maternal and offspring health. The triad mother-breast milk-infant is an interconnected system in which maternal diet and lifestyle might have effects on infant's health outcome. This link could be in part explained by epigenetics, even if the underlining mechanisms have not been fully clarified yet. The aim of this paper is to update the association between maternal diet and human milk, pointing out how maternal diet and lifestyle could be associated with breast-milk composition, hence with offspring's health outcome.
\end{abstract}

Keywords: breastfeeding; nutrition; obesity; microbiome; health outcomes

\section{Introduction}

In accordance with the World Health Organization (WHO), the American Academy of Pediatrics (AAP), and the European Society for Pediatric Gastroenterology, Hepatology and Nutrition (ESPGHAN), human milk represents the normative feeding for infants during the first six months of life and later, in addition to the complementary feeding [1,2]. In fact, human milk meets the infants' specific nutritional needs and leads to an adequate growth and functional development [3-6]. Increasing evidence has shown that breast milk provides not only nourishment for infants but also it reduces the risk of developing several diseases through the provision of bioactive factors including the occurrence of noncommunicable diseases such as obesity, type 2 diabetes mellitus, and cardiovascular disease later in life [7]. Breast milk allows mother-infant signaling within a closely linked system comprising the "mother-breast milk-infant" triad. Remarkably, variations occurring in each component of the triad appear to modulate the trajectory of infant development and maternal health [8].

We conducted a narrative review in order to provide an update on the available evidence regarding the association between maternal diet, lifestyle, and human milk composition. We searched the PubMed database for articles relating to breast milk using specific keywords such as breastmilk, human milk, maternal diet, nutritional, offspring outcome, microbiome. With regard to the maternal lifestyle we have chosen to focus on the most discussed topics in the recent literature, such as smoking, obesity, and plant-based diet. Preference was given to the sources published within the past 5 years. We included randomized controlled trials, cohort studies, systematic reviews, and meta-analysis. On the other hand, preclinical studies were excluded. 


\section{Nutrition during Pregnancy and Lactation}

\subsection{Energy Requirement}

The energy requirement of a healthy, normal weight woman might be moderately increased during pregnancy, depending on pregnancy stage. At the same time, all women should maintain an active and healthy lifestyle, avoiding smoking and preventing excessive weight gain [9]. In fact, excessive as well as deficiency intake of macronutrients could be very harmful for mothers, fetal development, and for both later health outcomes. On the other hand, only a small increase of energy intake is necessary for milk production during lactation $[10,11]$. It is well known that higher demands of energy during pregnancy need a moderate increase in the energy value of the diet. However, over alimentation and overweight are associated with an increased risk of spontaneous abortion, gestational diabetes, pre-eclampsia, and also with infants' development of type 2 diabetes and obesity during adult age $[10,11]$.

In order to support fetal development and promote infant growth, daily energy value should be increased by about $70 \mathrm{kcal} /$ day during the first trimester of pregnancy, $260 \mathrm{Kcal} /$ day in the second trimester, and $500 \mathrm{Kcal} /$ day in the third one and also during the first six months of exclusive breastfeeding, as recommended by the European Food Safety Authority (EFSA) [12]. Moreover, the energy cost of pregnancy is not equally distributed. In fact, energy deposition as protein occurs primarily in the third trimester $(80 \%)$, and energy deposition as fat is based on rate of weight gain [13].

\subsection{What about Macronutrients?}

Protein intake could play an important role in fetal growth. As a matter of fact, low assumption of protein during pregnancy could influence both the weight and length of the newborn, as well as a high intake of protein may be negatively related with fetal development [14]. As a result, international guidelines agree in suggesting that the maternal protein daily intake increases by $26 \mathrm{~g} /$ day in the third trimester of pregnancy and by $21 \mathrm{~g} /$ day in the first semester of exclusive breastfeeding and by $14 \mathrm{~g} /$ day later, if breast milk still represents the main part of infant's diet [9].

In our knowledge, a high protein intake during infancy is associated with an increased secretion of insulin and insulin growth factor (IGF-1) and so, with a greater early weight gain and with later obesity [15]. Even if breastfeeding has been related with a lower risk of future obesity, Forsum et al. showed that high maternal intake of proteins may be associated with higher levels of protein in breast milk [16]. In addition, Grunewald et al. in an observational study suggested that interindividual variations in human milk protein contents may contribute to modulate infant growth and lead to excessive weight gain even during full breastfeeding $[17,18]$.

One of the main sources of energy is represented by lipids. During pregnancy and breastfeeding, an optimal lipid intake is possibly important for infant's neurological and retinal development [19]. It is currently known that the quality of fats, rather than their total amount, plays a fundamental role. Most studies indicate a positive correlation between the fatty acid (FA) compositions in maternal diet and in breast milk [20], even if few other researchers did not show any association [21]. Moreover, there is high evidence of the role played by omega-3-polyunsaturated fats during pregnancy-in particular, docosahexaenoic acid (DHA) and arachidonic (ARA) acid [19]. According to recent literature, only fatty acids and vitamins profiles of human milk appear to be influenced by maternal diet [22,23].

Some authors studied the supplementation of DHA related to the psychomotor neurodevelopment in early life $[24,25]$ and its possible association with lower risk of prematurity and post-partum depression [22,26-30]. Low blood levels of DHA were associated with low consumption of fish rich in omega-3, for example in vegetarian women [31]. In fact, in most studies, the use of fish oil supplementation during pregnancy and lactation was associated with higher levels of DHA [31-33]. The use of newly analytical methods, combined with appropriate bioinformatics and lipidomic analyses offers major opportuni- 
ties to explore the physiological roles of complex lipids in early life and to achieve further improvements in nutritional strategies [19,34].

Marita de Waard et al. carried on a systematic review with the aim of exploring the correlation between maternal diet during lactation and infants' long-term health outcome [35] and discovered that ten different studies focused on the relationship between maternal supplementation of long-chain polyunsaturated fatty acid (LC-PUFA) and infant growth or later body composition, without evidence of secure and consistent short or long-term positive associations [36-44]. FA composition of breast milk varies based on different factors such as lactation stage, gestational age, maternal nutritional status, and maternal lipid storage, which is the main source of omega-6 [21]. In addition, recent studies have shown a correlation between maternal perinatal psychopathologies, such as depression, anxiety, stress, and human milk composition in terms of macronutrients and immune components, immunoglobulin A, hormones, and cortisol. Some recent studies has shown that lower levels of DHA in breast milk were found in those countries where the prevalence of maternal depression was higher, impairing the adequate neurodevelopment of the offspring [45].

Moreover, Hahn-Holbrook et al. in their observational study highlighted a link between higher level of omega-3 PUFAs in human milk and lower level of negative affectivity at 3 months of age for those infants who were fully breast-fed. The pathways through which omega-3 PUFAs influenced infant temperament are not known yet, but their anti-inflammatory properties or their faculty to regulate neurotransmission could be involved [46]. As a result of a possible close correlation between maternal diet and DHA and EPA composition of human milk, Hahn-Holbrook et al. have showed how the maternal diet can influence the levels of omega-3 PUFAs in milk and thus infant behavior, reducing the stress and sadness of the offspring [46].

Lactose reflects carbohydrate energy content and, after protein, it is the most represented component of human milk. It is associated with infant growth, and its total amount in breast milk seems not to be affected by maternal diet $[47,48]$. On the other hand, the amount and quality composition of human milk oligosaccharides (HMOs) vary substantially between women in accordance to different factors such as enzymatic activity, which determine the synthesis of fucosylated HMOs and other genetic and environmental factors, which are not completely understood nowadays [48-52]. A better understanding of the maternal factors that influence this variability could be important in terms of health prevention. Indeed, HMOs could influence gut microbiota development, infant health, cognitive development, and disease risk $[49,53,54]$. The potential role played by HMOs in modulating newborn's metabolism and infant growth is currently under investigation. Bardanzellu et al., in their observational study, found that a decreased breast milk content of Lacto-N-fucopentaose I and 2-Fucosyllactose ( $2^{\prime}$-FL) appears to be protective against an excessive weight gain, while an increased breast milk content of Lacto- $\mathrm{N}$-fucopentaose II could predispose to it [55]. In addition, Larsson et al. in an exploratory study found significant differences in $\mathrm{HMO}$ breast milk composition between a group of exclusively breast-fed infants with high weight gain compared to a group of infants with normal weight gain. Further studies are needed to identify the mechanisms underlining this correlation; however, the most plausible hypothesis is represented by the link between HMO and the infant microbiota. Gaining further knowledge into the association between the HMO breast milk composition and their functional implication is possibly important in view of their supplementation in infant formulas to optimize the intestinal microbiota and positively influence infant growth [56].

Research has focused on the differences between the preterm and term human milk. Most recent studies report that macronutrient composition changes are more related to postnatal time than to gestational age [57]. Preterm milk is characterized by a higher total amount of protein than in term one; however, an overall decrease in total protein content during lactation is observed [57]. On the other hand, fat and energy density appears to remain constant over lactation [58]. With regard to the lactose content, it is higher in 
preterm than in term milk but maintains stable concentrations over time [59]. Interestingly, Fischer Fumeaux et al., in a prospective cohort study, identified some gender differences, as human milk dedicated to male infants seemed to be richer in fat and energy [57].

\subsection{Micronutrients}

During pregnancy, micronutrients are possibly important not only for their biological activity but also for leading to their storage for both maternal and fetal needs [60]. For this reason, they could be supplemented [61].

\subsubsection{Iron and Other Minerals}

In pregnant women, iron requirement increases progressively in accordance to fetal needs and in accordance with its storage in fetal tissues. For this reason, women are exposed to a greater risk of iron deficiency, which is associated with increased risk of fetal growth failure, preterm labor, low birth weight, and post-partum hemorrhages [62,63]. Furthermore, recent evidences found a relationship between maternal insufficient iron intakes and higher possibility of cardiovascular disease for the infants in adult age [64]. On the contrary, an excess of iron supplementation might be associated with maternal development of oxidative stress, lipid peroxidation, impaired glucose metabolism, and gestational hypertension [65].

Despite these evidences, as shown in the study of Mahdavi et al. [66-68], the level of iron in breast milk does not appear to be related to the dietary intake, even if iron supplementation during lactation resulted in improved transferrin receptor levels and hematocrit [69].

Regarding other minerals, an adequate intake of calcium during pregnancy could play a role in fetal growth and development, even if its breast milk level is not substantially influenced by maternal diet intake [70].

In addition, iodine low intake during pregnancy may be associated with both maternal and infant negative outcomes, particularly regarding infant neurodevelopment [71].

\subsubsection{Vitamins}

Since there is a high prevalence of insufficient maternal levels of vitamin D, doctors recommend its supplementation during pregnancy and breastfeeding [72]. De Regil et al. in a Chocrane review [73] demonstrated that an adequate intake of vitamin D was associated with a minor risk of pre-eclampsia, prematurity, and low birth weight. On the contrary, insufficient levels were associated with low birth weight, altered bone development, respiratory infections, and allergic diseases in childhood [9,73]. Czech-Kowalska et al. [72] carried out a prospective randomized controlled trial and focused their attention on the supplementation of vitamin D during breastfeeding both in mother and in infants. Body composition and bone mass assessed with dual-energy X-ray absorptiometry (DXA) three weeks, three months, and six months after delivery were not significantly different between infants of mothers receiving $1200 \mathrm{IU} / \mathrm{d}$ of cholecalciferol and those of mothers receiving $400 \mathrm{IU} / \mathrm{d}$ [72]. On the other hand, other studies showed that a higher dose of Vitamin D3 supplementation (6400 IU/day) was safe for both mother and child and resulted in a higher maternal level of 25-hydroxy-D [74]. Moreover, Basile et al. in a randomized controlled trial, demonstrated that a higher dose of vitamin D supplementation (4000 IU/d) was more effective in increasing the breast milk level of vitamin D compared with a lower dose (2000 IU/d) [75]. Furthermore, the relationship between inadequate levels of vitamin $\mathrm{D}$ and cardiovascular disease, hypertension, and diabetes has been described [76].

As for folic acid, there is strong evidence to support maternal supplementation in order to prevent neural tube defects $[73,77]$.

Moreover, a positive correlation between maternal consumption of vitamin $\mathrm{C}$ and $\mathrm{A}$ and adequate levels in breast-milk was found in some observational studies, as shown by Kodentsova et al. [78], Salmenpera [79], Lietz et al. [80], and Da Silva et al. [81]. In fact, 
vitamin C is a milk antioxidant $[82,83]$, and vitamin A plays a possibly important role in vision, intercellular communication, cell growth, and cell differentiation [81].

\subsubsection{Phytochemicals}

Maternal diet can influence the offspring outcome, especially in terms of development, through the action of secondary plant metabolites commonly named as phytochemicals, such as flavonoids and carotenoids. Phytochemical intake occurs through the consumption of fruits and vegetables. Many of them could be antioxidant and anti-inflammatory agents and could reduce the risk of some chronic conditions (heart diseases, cancer, diabetes, and neurodegenerative disorders) [84]. Thus, adequate supplementation of maternal diet during pregnancy and lactation with fruit and vegetable is possibly important to guarantee an optimal concentration of flavoinoids and carotenoids both in maternal serum and breast milk [85]. Vishwanathan et al. in an observational study demonstrated that lutein is the predominant carotenoid in the brain, and its deposition in the human retina occurs early in life [85]. Zielinska et al. in their observational study showed a positive correlation between the concentration of omega-3 LC-PUFA and carotenoids in breast milk and infant motor and brain structural development [86]. Flavonoid contribution to infant's oxidative stability is less clear [86].

\section{Human Milk: A Contribution to the Development of Infant Gut Microbiota and Immunity}

Several hypotheses have been formulated in order to explain the complexity and great diversity of bacteria contained in breast milk [87]. The dynamic cycling of bacteria from maternal commensal skin flora to infant mouth flora is one of the identified mechanisms [88]; however, this retrograde flow does not fully explain the diversity of human milk microbes. Therefore, an entero-mammary pathway has been hypothesized, whereby maternal intestinal bacteria migrate to the mammary glands via an endogenous cellular route during pregnancy and lactation [89]. Thus, the modulation of maternal gut microbiota during pregnancy and lactation could have a direct association on infant health. Several perinatal factors could influence microbial transfer from mother to infant via breast milk. All the factors that could modify maternal microbiota of skin, oral cavity, vagina, and gut may contribute to the modulation of human milk microbiota, including the lactation period, the mode of delivery and gestational age, the use of antibiotics or other medicines, the maternal dietary habits, and nutritional status [90] (Figure 1).

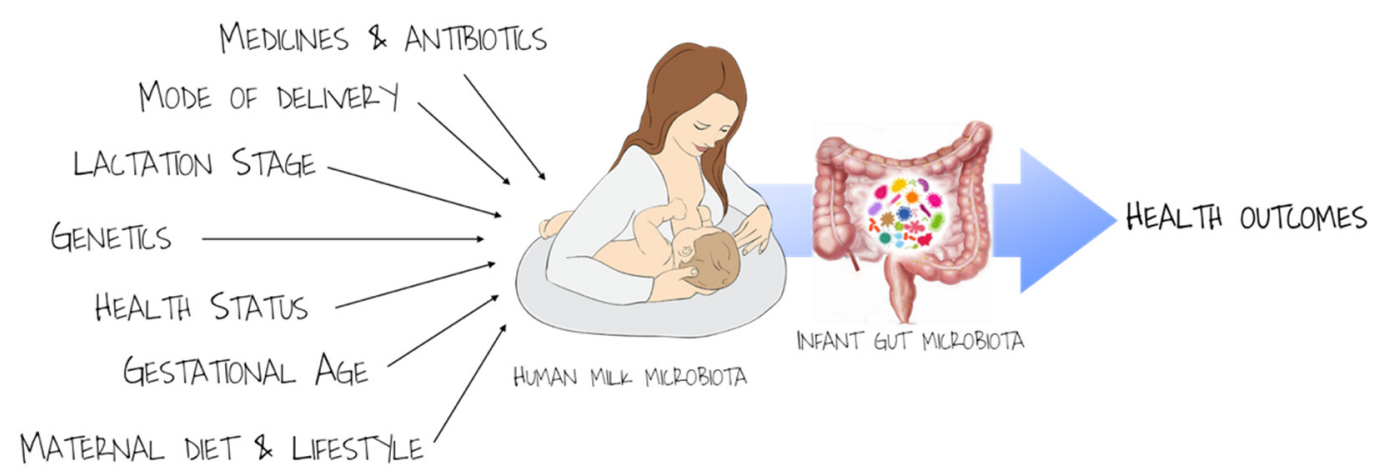

Figure 1. Modulation of infant gut microbiota via mother gut and human milk microbiota.

In particular, it is known that the gut microbiome composition differs in healthy and obese people; therefore, an aberrant microbiome can be vertically transmitted from an obese mother to her infant. Mother-to-newborn transmission of microbiota might be a causal factor underlying obesity's transmission [91,92]. 
Not only the breast milk microbiota but also the oligosaccharides and other components of human milk, including Immunoglobulin A (Ig A), can contribute to the composition and diversity of the infant gut microbiome [93].

Human milk-associated microbes are among the first to colonize the infant gut and may help to shape both short- and long-term infant health outcome [94]. Accordingly, a recent meta-analysis showed that exclusive breastfeeding, especially longer than 2 months from birth, was associated with a more stable gut bacterial taxa composition and reduced diarrhea-associated microbial dysbiosis [95]. The critical window of immune development and the community types may induce metabolic alterations, leading to differing immune phenotypes and long-term health outcomes [46,88,96-98]. Crosstalk between host cells (e.g., intestinal brush border cells or immune cells) and the colonizing microbiota is likely to be critical for metabolic development and the programming of body immune system in infants $[88,93]$.

4. Maternal Lifestyle and Nutritional Status during Pregnancy and Lactation and Later Health of Offspring: Some Traps

\subsection{Tobacco Smoking}

It is widely reported that maternal smoking during pregnancy and breastfeeding may be associated with negative outcomes of infants both at birth and later in life [99-101].

In particular, both the quantity and quality of breast milk might be negatively influenced by smoking just more than ten cigarettes per day [102]. Banderali et al. performed a descriptive review about associations of parental smoking during pregnancy and breastfeeding [103]. Recent observational studies showed a relationship between maternal smoking during pregnancy and the adverse outcomes at birth, such as low birth weight, prematurity $[104,105]$, and negative outcomes on fetal brain development [100]. According to some authors, maternal tobacco could be associated with mammary glands synthesis and the secretion of DHA into breast milk [106,107]. Other observational studies demonstrated that fetal growth impairment might be also influenced by epigenetic factors through DNA methylation of particular genes, such as Cytochrome P450 1A1 (CYP1A1) promoter [108-110].

Recent evidences highlighted that maternal smoking during pregnancy was associated with increased risk of Sudden Unexpected Infant Death [111]. Moreover, it could be associated with increased risk of infants' overweight, obesity, and metabolic diseases later in life [112-115]. Furthermore, some authors reported that there might be an association between hypertension and maternal smoking during pregnancy [116]. Last but not least, exposure to maternal tobacco was demonstrated to be related to higher incidence of respiratory tract diseases, such as airway hyper-responsiveness, wheezing, asthma, impaired lung function, and bronchitis [117]. Recent literature focused on the possible correlations of second- and third-hand smoking exposure on children outcomes [103,118].

Despite all these possible correlations, breast milk still remains the best feeding, even if the mother continues to smoke [119].

\subsection{Obesity}

Obesity represents one of the major public health issue all over the world. More than $20 \%$ of children in Europe and more than 30\% in the United States suffer from obesity or overweight [35].

Obesity in childhood increases the risk of developing cardiovascular or metabolic diseases early in life. The fetal-infant programming hypothesis tried to explain how to prevent obesity in childhood by modifying the maternal diet and therefore the fetal exposure to excessive nutrients intake [120-123].

Over alimentation and overweight during pregnancy are associated with an increased risk of spontaneous abortion, gestational diabetes, and pre-eclampsia [10,11]. Moreover, children of overweight or obese mothers are at greater risk of having a high birth weight 
for gestational age, a rapid weight gain in the first year, and becoming obese in adulthood (Table 1).

Table 1. Effect of maternal obesity on the mother-baby dyad.

\begin{tabular}{cc}
\hline Side Effects on Mother & Maternal Obesity \\
\hline $\begin{array}{c}\text { spontaneous abortion } \\
\text { gestational diabetes } \\
\text { pre-eclampsia }\end{array}$ & Side Effects on Infant \\
\hline
\end{tabular}

Thus, special attention might be paid to lifestyle interventions, such as education and behavioral counseling related to diet and physical activity, that can be applied both during pregnancy and breastfeeding [124].

The correlation between breastfeeding and reduced risk of obesity later in life has been widely discussed in order to prevent rapid acceleration of growth during infancy and reducing the deposition of adipose tissue [125-127]. Haschke et al. [128] examined data from three randomized controlled trials, with the aim of exploring the association between maternal obesity and faster growth of their breast-fed infants [129,130]. Moreover, the authors focused on the effect of low-protein formula on infant growth. Results showed that infants fed with low protein amount formula may grow slower than those fed with high protein content formula, and this might represent a strategy to reduce the risk of obesity later in life [131-133].

In accordance, Inostroza et al. in a randomized double-blind study demonstrated that breast-fed infants of obese mothers may show a more rapid growth than infants of normal-weight mothers, particularly during the first six months of life [129].

Recent evidences confirmed that breast-milk composition was influenced by maternal nutritional status. Some studies analyzed the breast-milk composition of healthy and obese mothers and demonstrated the presence of different amounts of fatty acids, protein, and calories [134-136]. In particular, Leghi et al. in a recent systematic review highlighted an association between maternal obesity or overweight and fat and lactose concentration in human milk depending on different lactation stage; on the other hand, no correlation was found with protein concentration [92]. De Luca et al. aimed to compare breast-milk composition of obese versus normal-weight mothers. In their cross-sectional observational study, they found a higher amount of leptin in breast milk of obese mothers, whereas breast milk was not different in terms of protein, lipid, and carbohydrate composition and volume $[137,138]$. Leptin content has also been positively correlated with higher weight gain in infants and increased adiposity as far as 12 months of lactation. In fact, researchers have found a correlation between breast-milk leptin and infant serum leptin, and between infant serum leptin and both infant BMI and weight [139]. Kirchberg et al. identified different metabolic clusters in a cohort of breast-fed infants of 6 months old. They emphasized the heterogeneity of metabolic patterns characterizing breast-fed infants; however, further studies are needed to examine the potential role of these data to predict the risk of obesity in childhood [140]. In addition, a recent cohort study by Samuel et al. suggested that the HMO breast milk composition varies depending on different factors such as pre-pregnancy body mass index (BMI), mode of delivery, and parity. In particular, pre-pregnancy BMI might influence maternal HMO glycosylation and could contribute to the increased obesity risk in children of obese mothers [141].

\subsection{Plant-Based Diet}

There is no consensus regarding the relationship between vegetarianism and health outcomes of both mothers and babies. The American Academy of Nutrition and Dietetics $[142,143]$ argued that a well-balanced plant based diet is safe and supports sustainable growth and development in all age groups. On the contrary, the Swiss Federal Commission for Nutrition [144], the German Nutrition Society (DGE) [145], and ESPGHAN [146] 
do not recommend the adoption of a vegan diet during pregnancy or lactation, in order to avoid the development of nutritional deficiencies. Moreover, the importance of adequate supplementation and nutrition counseling for these groups of women has been highlighted [146,147].

In addition, plant-based diets during lactation still raises doubts about human milk donations. According to the European Milk Bank Association (EMBA) Guidelines, mothers following a vegan diet without an adequate supplementation should not donate their milk [148].

Vegetarian and vegan diets are associated with major risk of nutritional deficiencies compared to omnivorous one, but update evidences highlight that if adequately supplemented, vegetarian and vegan diets could be considered safe for mothers and the offspring health during pregnancy and lactation $[9,149,150]$. Plant-based diets have been reported to contain more folate, fiber, antioxidants, and carotenoids and less saturated fatty acids, protein, and cholesterol [151], on the other hand, a low content of essential micronutrients especially in terms of iron, zinc, vitamin B12 [152], vitamin D, omega-3 (n-3) fatty acids, calcium, and iodine has been described inn vegetarian diet [153]. For this reason, micronutrient deficiencies might not be underestimated [149].

\subsection{Chemical Residues}

Unfortunately, breast milk is not pristine, and this is due to environmental pollution. Contamination of human milk is widespread [154]. Polychlorinated biphenyls (PCBs), dichlorodiphenyltrichloroethane (DDT) and its metabolites, dioxins, dibenzofurans, polybrominated diphenyl ethers (PBDEs), and heavy metals are the main chemical contaminants most commonly found in breast milk. Exposition to lipophilic toxic chemicals occurs in everyday life through the air, water, and food, both at home or at the workplace [155]. Generally, pollutants enter breast milk by passive transfer from maternal plasma, and their concentration is proportional to their lipophilicity and solubility [154]. Despite its importance, few studies have been conducted on this topic, but the data obtained so far would seem encouraging. Van den Berg et al. conducted a global survey indicating that the human exposure to polychlorinated biphenyls and dioxin-like compounds is still above those considered toxicologically safe for the fetus and breast-fed infant [156].

\section{Conclusions}

Breast milk represents a complex and dynamic system that allows mother-infant communication and signaling. The components of the "mother-breast milk-infant" triad are closely connected to each other, and every single variation could affect the trajectory of infant development or maternal health [8]. Taking care of women's health, in terms of diet and lifestyle, during the preconception period, pregnancy, and breastfeeding could represent a prevention strategy in terms of improving the offspring health [157]. Nowadays, the increased percentage of women who follow elimination diets by choice or by necessity underlines the importance of providing specialist care in order to prevent malnutrition and the adverse associations with maternal health and infant's growth and development [151].

As this is a narrative review, this study does not provide an exhaustive account of all available literature, but it attempts to give a broad overview of existing evidence published on the triad mother-breast milk-infant. Moreover, a limitation of this review is that, despite a Mendelian randomization study and ten clinical trials, the vast majority of the considered studies were observational ones so, by their nature, they run the risk of containing confounding biases. The associations noted in observational studies such as between breastfeeding and outcomes might be actually due to the influence of the social determinants of health. The social determinants of health include opportunities for education and employment, level of income, ethnicity, race, access to housing and affordable utilities, access to health care, social and community support, early childhood education, neighborhood crime rates, and access to transportation and leisure activities [158]. Improving public health passes from health equity and measures to reduce disparities should be 
integrated into health programs and services $[1,2][159,160]$. Health and social workers need to understand the importance of social determinants of health and to work together to make available the best health opportunities for all the population. Addressing the social determinants of health could represent a winning strategy for promoting more equitable health outcomes for patients, families, and communities [159]. On the other hand, even though some social determinants of health can be modifiable by supportive environments or clinical preventive practices and health programs, many of these when considered at the maternal level can result from upstream and insidious structural forces at play that go beyond maternal choices and immediate social and economic opportunities [159]. Social determinants of health, even if not modifiable and not dependent on maternal choices, could play a role on mother's health and infant development individually and on the mother-breast milk-infant triad. In a recent cross-sectional study conducted by Gea Horta et al., factors associated with nutritional outcomes in 3676 mother-child dyads at the household level were analyzed, and it was pointed out that lower maternal education levels and living in inadequate households were associated with the double burden of malnutrition and the lack of breastfeeding was associated with maternal overweight [160]. Moreover adverse social determinants could affect breastfeeding initiation and early cessation as evaluated in a cohort study by Newhook at al. [161]. In fact, a socioeconomically disadvantaged population with low levels of education and income seems to be much less likely to breast-fed than their peers with higher levels of income and education [161]. In this kind of population, community support systems, such as trained health workers, lactation consultants, and community leaders, become essential to sustain breastfeeding [162].

By the end, social determinants of health appear to modulate maternal physiology and nutritional status and thus breast milk composition, which, in turn, could be associated with infant growth and health outcomes. Further studies are needed to achieve better knowledge about the mechanisms underlining this association [163] and define the prevention and therapeutic strategies aimed to promote infants' growth, development, and health.

Author Contributions: Conceptualization, E.V., M.L.G.; resources, G.V., S.V., J.C.; writing-original draft preparation, E.V., G.V.; writing—review and editing, E.V., M.L.G.; supervision, F.M., G.V.Z. All authors have read and agreed to the published version of the manuscript.

Funding: This research received no external funding.

Institutional Review Board Statement: Not applicable.

Informed Consent Statement: Not applicable.

Data Availability Statement: Not applicable.

Conflicts of Interest: The authors declare no conflict of interest.

\section{References}

1. Eidelman, A.I.; Schanler, R.J. Breastfeeding and the use of human milk. Pediatrics 2012, 129, e827-e841.

2. Agostoni, C.; Braegger, C.; Decsi, T.; Kolacek, S.; Koletzko, B.; Michaelsen, K.F.; Mihatsch, W.; Moreno, L.A.; Puntis, J.; Shamir, R.; et al. Breast-feeding: A commentary by the espghan Committee on Nutrition. J. Pediatrics Gastroenterol. Nutr. 2009, 49, 112-125. [CrossRef]

3. Mulligan, P.; White, N.R.J.; Monteleone, G.; Wang, P.; Wilson, J.W.; Ohtsuka, Y.; Sanderson, I.R. Breast milk lactoferrin regulates gene expression by binding bacterial DNA CpG motifs but not genomic DNA promoters in model intestinal cells. Pediatric Res. 2006, 59, 656-661. [CrossRef]

4. Minekawa, R.; Takeda, T.; Sakata, M.; Hayashi, M.; Isobe, A.; Yamamoto, T.; Tasaka, K.; Murata, Y. Human breast milk suppresses the transcriptional regulation of IL-1 $\beta$-induced NF-KB signaling in human intestinal cells. Am. J. Physiol. Cell Physiol. 2004, 287. [CrossRef]

5. Barouki, R.; Gluckman, P.D.; Grandjean, P.; Hanson, M.; Heindel, J.J. Developmental origins of non-communicable disease: Implications for research and public health. Environ. Health A Glob. Access Sci. Source 2012, 11, 1-9. [CrossRef]

6. Agostoni, C.; Baselli, L.; Mazzoni, M.B. Early nutrition patterns and diseases of adulthood: A plausible link? Eur. J. Intern. Med. 2013, 24, 5-10. [CrossRef]

7. Verduci, E.; Giannì, M.L.; Di Benedetto, A. Human milk feeding in preterm infants: What has been done and what is to be done. Nutrients 2020, 12, 44. [CrossRef] 
8. Bode, L.; Raman, A.S.; Murch, S.H.; Rollins, N.C.; Gordon, J.I. Understanding the mother-breastmilk-infant "triad". Science 2020, 367, 1070-1072. [CrossRef]

9. Marangoni, F.; Cetin, I.; Verduci, E.; Canzone, G.; Giovannini, M.; Scollo, P.; Corsello, G.; Poli, A. Maternal diet and nutrient requirements in pregnancy and breastfeeding. An Italian consensus document. Nutrients 2016, 8, 629. [CrossRef]

10. Bruce, K.D. Maternal and in utero determinants of type 2 diabetes risk in the young. Curr. Diab. Rep. 2014, 14. [CrossRef]

11. Catalano, P.; Demouzon, S.H. Maternal obesity and metabolic risk to the offspring: Why lifestyle interventions may have not achieved the desired outcomes. Int. J. Obes. 2015, 39, 642-649. [CrossRef]

12. Scientific Opinion on Dietary Reference Values for Energy. EFSA J. 2013, 11. [CrossRef]

13. Butte, N.F.; King, J.C. Energy requirements during pregnancy and lactation. Public Health Nutr. 2005, 8, 1010-1027. [CrossRef]

14. Kramer, M.S.; Kakuma, R. Energy and protein intake in pregnancy. In Cochrane Database of Systematic Reviews; John Wiley \& Sons, Ltd.: Hoboken, NJ, USA, 2003. [CrossRef]

15. Saure, C.; Armeno, M.; Barcala, C.; Giudici, V.; Mazza, C.S. Excessive weight gain in exclusively breast-fed infants. J. Pediatric Endocrinol. Metab. 2017, 30, 719-724. [CrossRef]

16. Forsum, E.; Lonnerdal, B. Effect of protein intake on protein and nitrogen composition of breast milk. Am. J. Clin. Nutr. 1980, 33, 1809-1813. [CrossRef]

17. Grunewald, M.; Hellmuth, C.; Demmelmair, H.; Koletzko, B. Excessive Weight Gain during Full Breast-Feeding. Ann. Nutr. Metab. 2014, 64, 271-275. [CrossRef]

18. De La Presa-Owens, S.; López-Sabater, M.C.; Rivero-Urgell, M. Fatty acid composition of human milk in Spain. J. Pediatr. Gastroenterol. Nutr. 1996, 22, 180-185. [CrossRef]

19. Koletzko, B. Human milk lipids. Ann. Nutr. Metab. 2017, 69, 28-40. [CrossRef]

20. Morrow, A.L.; Dawodu, A. Fatty Acids and Fat-Soluble Vitamins in Breast Milk: Physiological Significance and Factors Affecting Their Concentrations. Nestle Nutr. Inst. Workshop Ser. 2019, 90, 57-67. [CrossRef]

21. Keikha, M.; Bahreynian, M.; Saleki, M.; Kelishadi, R. Macro- and Micronutrients of Human Milk Composition: Are They Related to Maternal Diet? A Comprehensive Systematic Review. Breastfeed. Med. 2017, 12, 517-527. [CrossRef]

22. Innis, S.M.; Friesen, R.W. Essential n-3 fatty acids in pregnant women and early visual acuity maturation in term infants. Am. J. Clin. Nutr. 2008, 87, 548-557. [CrossRef]

23. Lonnerdal, B. Effects of maternal dietary intake on human milk composition. J. Nutr. 1986, 116, 499-513. [CrossRef]

24. Jasani, B.; Simmer, K.; Patole, S.K.; Rao, S.C. Long chain polyunsaturated fatty acid supplementation in infants born at term. Cochrane Database Syst. Rev. 2017, 2017. [CrossRef]

25. Shulkin, M.; Pimpin, L.; Bellinger, D.; Kranz, S.; Fawzi, W.; Duggan, C.; Mozaffarian, D. N-3 fatty acid supplementation in mothers, preterm infants, and term infants and childhood psychomotor and visual development: A systematic review and meta-analysis. J. Nutr. 2018, 148, 409-418. [CrossRef]

26. Koletzko, B.; Agostoni, C.; Bergmann, R.; Ritzenthaler, K.; Shamir, R. Physiological aspects of human milk lipids and implications for infant feeding: A workshop report. Acta Paediatr. 2011, 100, 1405-1415. [CrossRef]

27. Lauritzen, L.; Carlson, S.E. Maternal fatty acid status during pregnancy and lactation and relation to newborn and infant status. Matern. Child Nutr. 2011, 7, 41-58. [CrossRef]

28. Sallis, H.; Steer, C.; Paternoster, L.; Davey Smith, G.; Evans, J. Perinatal depression and omega-3 fatty acids: A Mendelian randomisation study. J. Affect. Disord. 2014, 166, 124-131. [CrossRef]

29. Mennitti, L.V.; Oliveira, J.L.; Morais, C.A.; Estadella, D.; Oyama, L.M.; Oller do Nascimento, C.M.; Pisani, L.P. Type of fatty acids in maternal diets during pregnancy and/or lactation and metabolic consequences of the offspring. J. Nutr. Biochem. 2015, 26, 99-111. [CrossRef]

30. Tian, H.M.; Wu, Y.X.; Lin, Y.Q.; Chen, X.Y.; Yu, M.; Lu, T.; Xie, L. Dietary patterns affect maternal macronutrient intake levels and the fatty acid profile of breast milk in lactating Chinese mothers. Nutrition 2019, 58, 83-88. [CrossRef]

31. Michaelsen, K.F.; Dewey, K.G.; Perez-Exposito, A.B.; Nurhasan, M.; Lauritzen, L.; Roos, N. Food sources and intake of n-6 and n-3 fatty acids in low-income countries with emphasis on infants, young children (6-24 months), and pregnant and lactating women. Matern. Child Nutr. 2011, 7, 124-140. [CrossRef]

32. Dunstan, J.A.; Mori, T.A.; Barden, A.; Beilin, L.J.; Taylor, A.L.; Holt, P.G.; Prescott, S.L. Fish oil supplementation in pregnancy modifies neonatal allergen-specific immune responses and clinical outcomes in infants at high risk of atopy: A randomized, controlled trial. J. Allergy Clin. Immunol. 2003, 112, 1178-1184. [CrossRef]

33. Copp, K.; DeFranco, E.A.; Kleiman, J.; Rogers, L.K.; Morrow, A.L.; Valentine, C.J. Nutrition Support Team Guide to Maternal Diet for the Human-Milk-Fed Infant. Nutr. Clin. Pract. 2018, 33, 687-693. [CrossRef]

34. de Waard, M.; Brands, B.; Kouwenhoven, S.M.P.; Lerma, J.C.; Crespo-Escobar, P.; Koletzko, B.; Zalewski, B.M.; van Goudoever, J.B. Optimal nutrition in lactating women and its effect on later health of offspring: A systematic review of current evidence and recommendations (EarlyNutrition project). Crit. Rev. Food Sci. Nutr. 2017, 57, 4003-4016. [CrossRef]

35. Campoy, C.; Escolano-Margarit, V.; Anjos, T.; Szajewska, H.; Uauy, R. Omega 3 fatty acids on child growth, visual acuity and neurodevelopment. Br. J. Nutr. 2012, 107, S85-S106. [CrossRef]

36. Muhlhausler, B.S.; Gibson, R.A.; Makrides, M. Effect of long-chain polyunsaturated fatty acid supplementation during pregnancy or lactation on infant and child body composition: A systematic review. Am. J. Clin. Nutr. 2010, 92, 857-863. [CrossRef] 
37. Rodríguez, G.; Iglesia, I.; Bel-Serrat, S.; Moreno, L.A. Effect of n-3 long chain polyunsaturated fatty acids during the perinatal period on later body composition. Br. J. Nutr. 2012, 107, S117-S128. [CrossRef]

38. Martínez-Victoria, E.; Yago, M.D. Omega 3 polyunsaturated fatty acids and body weight. Br. J. Nutr. 2012, 107, S107-S116. [CrossRef]

39. Stratakis, N.; Gielen, M.; Chatzi, L.; Zeegers, M.P. Effect of maternal n-3 long-chain polyunsaturated fatty acid supplementation during pregnancy and/or lactation on adiposity in childhood: A systematic review and meta-analysis of randomized controlled trials. Eur. J. Clin. Nutr. 2014, 68, 1277-1287. [CrossRef]

40. Delgado-Noguera, M.F.; Calvache, J.A.; Bonfill Cosp, X.; Kotanidou, E.P.; Galli-Tsinopoulou, A. Supplementation with long chain polyunsaturated fatty acids (LCPUFA) to breastfeeding mothers for improving child growth and development. Cochrane Database Syst. Rev. 2015, 2015. [CrossRef]

41. Jensen, C.L.; Voigt, R.G.; Llorente, A.M.; Peters, S.U.; Prager, T.C.; Zou, Y.L.; Rozelle, J.C.; Turcich, M.R.; Fraley, J.K.; Anderson, R.E.; et al. Effects of early maternal docosahexaenoic acid intake on neuropsychological status and visual acuity at five years of age of breast-fed term infants. J. Pediatrics 2010, 157, 900-905. [CrossRef]

42. Bergmann, R.L.; Bergmann, K.E.; Richter, R.; Haschke-Becher, E.; Henrich, W.; Dudenhausen, J.W. Does docosahexaenoic acid (DHA) status in pregnancy have any impact on postnatal growth? Six-year follow-up of a prospective randomized double-blind monocenter study on low-dose DHA supplements. J. Perinat. Med. 2012, 40, 677-684. [CrossRef]

43. Brei, C.; Stecher, L.; Much, D.; Karla, M.-T.; Amann-Gassner, U.; Shen, J.; Ganter, C.; Karampinos, D.C.; Brunner, S.; Hauner, H. Reduction of the n-6:n-3 long-chain PUFA ratio during pregnancy and lactation on offspring body composition: Follow-up results from a randomized controlled trial up to 5 y of age. Am. J. Clin. Nutr. 2016, 103, 1472-1481. [CrossRef]

44. Di Benedetto, M.G.; Bottanelli, C.; Cattaneo, A.; Pariante, C.M.; Borsini, A. Nutritional and immunological factors in breast milk: A role in the intergenerational transmission from maternal psychopathology to child development. Brain Behav. Immun. 2020, 85, 57-68. [CrossRef]

45. Hahn-Holbrook, J.; Fish, A.; Glynn, L.M. Human milk omega-3 fatty acid composition is associated with infant temperament. Nutrients 2019, 11, 2964. [CrossRef]

46. Aumeistere, L.; Ciproviča, I.; Zavadska, D.; Andersons, J.; Volkovs, V.; Celmalniece, K. Impact of Maternal Diet on Human Milk Composition Among Lactating Women in Latvia. Medicina 2019, 55, 173. [CrossRef]

47. Gay, M.C.; Koleva, P.T.; Slupsky, C.M.; du Toit, E.; Eggesbo, M.; Johnson, C.C.; Wegienka, G.; Shimojo, N.; Campbell, D.E.; Prescott, S.L.; et al. Worldwide Variation in Human Milk Metabolome: Indicators of Breast Physiology and Maternal Lifestyle? Nutrients 2018, 10, 1151. [CrossRef]

48. Azad, M.B.; Robertson, B.; Atakora, F.; Becker, A.B.; Subbarao, P.; Moraes, T.J.; Mandhane, P.J.; Turvey, S.E.; Lefebvre, D.L.; Sears, M.R.; et al. The Journal of Nutrition Nutrient Physiology, Metabolism, and Nutrient-Nutrient Interactions Human Milk Oligosaccharide Concentrations Are Associated with Multiple Fixed and Modifiable Maternal Characteristics, Environmental Factors, and Feeding Practices. J. Nutr. 2018, 148, 1733-1742. [CrossRef]

49. Quin, C.; Vicaretti, S.D.; Mohtarudin, N.A.; Garner, A.M.; Vollman, D.M.; Gibson, D.L.; Zandberg, W.F.; Hart, G.W. Influence of sulfonated and diet-derived human milk oligosaccharides on the infant microbiome and immune markers. J. Biol. Chem. 2020, 295, 4035-4048. [CrossRef]

50. Maessen, S.E.; Derraik, J.G.B.; Binia, A.; Cutfield, W.S. Perspective: Human Milk Oligosaccharides: Fuel for Childhood Obesity Prevention. Adv. Nutr. 2020, 11, 35-40. [CrossRef]

51. Lagström, H.; Rautava, S.; Ollila, H.; Kaljonen, A.; Turta, O.; Mäkelä, J.; Yonemitsu, C.; Gupta, J.; Bode, L. Associations between human milk oligosaccharides and growth in infancy and early childhood. Am. J. Clin. Nutr. 2020, 111, 769-778. [CrossRef]

52. Vandenplas, Y.; Carnielli, V.P.; Ksiazyk, J.; Luna, M.S.; Migacheva, N.; Mosselmans, J.M.; Picaud, J.C.; Possner, M.; Singhal, A.; Wabitsch, M. Factors affecting early-life intestinal microbiota development. Nutrition 2020, 78, 110812. [CrossRef]

53. Berger, P.K.; Plows, J.F.; Jones, R.B.; Alderete, T.L.; Yonemitsu, C.; Poulsen, M.; Ryoo, J.H.; Peterson, B.S.; Bode, L.; Goran, M.I. Human milk oligosaccharide $2^{\prime}$-fucosyllactose links feedings at 1 month to cognitive development at 24 months in infants of normal and overweight mothers. PLOS ONE 2020, 15. [CrossRef]

54. Bardanzellu, F.; Puddu, M.; Peroni, D.G.; Fanos, V. The Human Breast Milk Metabolome in Overweight and Obese Mothers. Front. Immunol. 2020, 11, 1533. [CrossRef]

55. Larsson, M.W.; Lind, M.V.; Laursen, R.P.; Yonemitsu, C.; Larnkjær, A.; Mølgaard, C.; Michaelsen, K.F.; Bode, L. Human Milk Oligosaccharide Composition Is Associated With Excessive Weight Gain During Exclusive Breastfeeding-An Explorative Study. Front. Pediatrics 2019, 7, 297. [CrossRef]

56. Fischer Fumeaux, C.J.; Garcia-Rodenas, C.L.; De Castro, C.A.; Courtet-Compondu, M.C.; Thakkar, S.K.; Beauport, L.; Tolsa, J.F.; Affolter, M. Longitudinal Analysis of Macronutrient Composition in Preterm and Term Human Milk: A Prospective Cohort Study. Nutrients 2019, 11, 1525. [CrossRef]

57. Pérez-Gálvez, A.; Calvo, M.V.; Megino-Tello, J.; Aguayo-Maldonado, J.; Jiménez-Flores, R.; Fontecha, J. Effect of gestational age (preterm or full term) on lipid composition of the milk fat globule and its membrane in human colostrum. J. Dairy Sci. 2020, 103, 7742-7751. [CrossRef]

58. Gidrewicz, D.A.; Fenton, T.R. A systematic review and meta-analysis of the nutrient content of preterm and term breast milk. BMC Pediatrics 2014, 14, 216. [CrossRef]

59. Dror, D.K.; Allen, L.H. Overview of nutrients in humanmilk. Adv. Nutr. 2018, 9, 278S-294S. [CrossRef] 
60. Koletzko, B.; Bauer, C.P.; Bung, P.; Cremer, M.; Flothkötter, M.; Hellmers, C.; Kersting, M.; Krawinkel, M.; Przyrembel, H.; Rasenack, R.; et al. German National Consensus Recommendations on Nutrition and Lifestyle in Pregnancy by the "Healthy Start-Young Family Network". Ann. Nutr. Metab. 2013, 63, 311-322. [CrossRef]

61. Allen, L.H. Anemia and iron deficiency: Effects on pregnancy outcome. Am. J. Clin. Nutr. 2000, 71, 1280S-1284S. [CrossRef]

62. Khambalia, A.Z.; Collins, C.E.; Roberts, C.L.; Morris, J.M.; Powell, K.L.; Tasevski, V.; Nassar, N. Iron deficiency in early pregnancy using serum ferritin and soluble transferrin receptor concentrations are associated with pregnancy and birth outcomes. Eur. J. Clin. Nutr. 2016, 70, 358-363. [CrossRef]

63. Alwan, N.A.; Hamamy, H. Maternal Iron Status in Pregnancy and Long-Term Health Outcomes in the Offspring. J. Pediatric Genet. 2015, 4, 111-123. [CrossRef]

64. Krebs, N.F.; Domellö,, M.; Ziegler, E. Balancing benefits and risks of iron fortification in resource-rich countries. J. Pediatric 2015, 167, S20-S25. [CrossRef]

65. Mahdavi, R.; Nikniaz, L.; Gayemmagami, S.J. Association between zinc, copper, and iron concentrations in breast milk and growth of healthy infants in Tabriz, Iran. Biol. Trace Elem. Res. 2010, 135, 174-181. [CrossRef]

66. Nakamori, M.; Ninh, N.X.; Isomura, H.; Yoshiike, N.; Hien, V.T.T.; Nhug, B.T.; Van Nhien, N.; Nakano, T.; Khan, N.C.; Yamamoto, S. Nutritional status of lactating mothers and their breast milk concentration of iron, zinc and copper in rural Vietnam. J. Nutr. Sci. Vitaminol. (Tokyo) 2009, 55, 338-345. [CrossRef]

67. Choi, Y.K.; Kim, J.-M.; Lee, J.-E.; Cho, M.S.; Kang, B.S.; Choi, H.; Kim, Y. Association of Maternal Diet With Zinc, Copper, and Iron Concentrations in Transitional Human Milk Produced by Korean Mothers. Clin. Nutr. Res. 2016, 5, 15-25. [CrossRef]

68. Khambalia, A.; Latulippe, M.E.; Campos, C.; Merlos, C.; Villalpando, S.; Picciano, M.F.; O'Connor, D.L. Milk folate secretion is not impaired during iron deficiency in humans. J. Nutr. 2006, 136, 2617-2624. [CrossRef]

69. Maru, M.; Birhanu, T.; Tessema, D.A. Calcium, magnesium, iron, zinc and copper, compositions of human milk from populations with cereal and "enset" based diets. Ethiop. J. Health Sci. 2013, 23, 90-97.

70. Trumpff, C.; Vandevijvere, S.; Moreno-Reyes, R.; Vanderpas, J.; Tafforeau, J.; Van Oyen, H.; De Schepper, J. Neonatal thyroidstimulating hormone level is influenced by neonatal, maternal, and pregnancy factors. Nutr. Res. 2015, 35, 975-981. [CrossRef]

71. Czech-Kowalska, J.; Latka-Grot, J.; Bulsiewicz, D.; Jaworski, M.; Pludowski, P.; Wygledowska, G.; Chazan, B.; Pawlus, B.; Zochowska, A.; Borszewska-Kornacka, M.K.; et al. Impact of vitamin D supplementation during lactation on vitamin D status and body composition of mother-infant pairs: A MAVID randomized controlled trial. PLoS ONE 2014, 9, e107708. [CrossRef]

72. De-Regil, L.M.; Palacios, C.; Lombardo, L.K.; Peña-Rosas, J.P. Vitamin D supplementation for women during pregnancy. Cochrane Database Syst. Rev. 2016, 2016. [CrossRef]

73. Wagner, C.L.; Hulsey, T.C.; Fanning, D.; Ebeling, M.; Hollis, B.W. High-dose vitamin D3 supplementation in a cohort of breastfeeding mothers and their infants: A 6-month follow-up pilot study. Breastfeed. Med. 2006, 1, 59-70. [CrossRef]

74. Basile, L.A.; Taylor, S.N.; Wagner, C.L.; Horst, R.L.; Hollis, B.W. The effect of high-dose vitamin D supplementation on serum vitamin D levels and milk calcium concentration in lactating women and their infants. Breastfeed. Med. 2006, 1, 27-35. [CrossRef]

75. Pludowski, P.; Holick, M.F.; Pilz, S.; Wagner, C.L.; Hollis, B.W.; Grant, W.B.; Shoenfeld, Y.; Lerchbaum, E.; Llewellyn, D.J.; Kienreich, K.; et al. Vitamin D effects on musculoskeletal health, immunity, autoimmunity, cardiovascular disease, cancer, fertility, pregnancy, dementia and mortality-A review of recent evidence. Autoimmun. Rev. 2013, 12, 976-989. [CrossRef]

76. Cawley, S.; Mullaney, L.; McKeating, A.; Farren, M.; McCartney, D.; Turner, M.J. A review of European guidelines on periconceptional folic acid supplementation. Eur. J. Clin. Nutr. 2016, 70, 143-154. [CrossRef]

77. Kodentsova, V.M.; Vrzhesinskaya, O.A. Evaluation of the vitamin status in nursing women by vitamin content in breast milk. Bull. Exp. Biol. Med. 2006, 141, 323-327. [CrossRef]

78. Salmenpera, L. Vitamin C nutrition during prolonged lactation: Optimal in infants while marginal in some mothers. Am. J. Clin. Nutr. 1984, 40, 1050-1056. [CrossRef]

79. Lietz, G.; Henry, C.J.K.; Mulokozi, G.; Mugyabuso, J.K.L.; Ballart, A.; Ndossi, G.D.; Lorri, W.; Tomkins, A. Comparison of the effects of supplemental red palm oil and sunflower oil on maternal vitamin A status. Am. J. Clin. Nutr. 2001, 74, 501-509. [CrossRef]

80. da Silva, A.G.C.L.; de Sousa Rebouças, A.; Mendonça, B.M.A.; Silva, D.C.N.E.; Dimenstein, R.; Ribeiro, K.D.D.S. Relationship between the dietary intake, serum, and breast milk concentrations of vitamin A and vitamin $\mathrm{E}$ in a cohort of women over the course of lactation. Matern. Child Nutr. 2019, 15. [CrossRef]

81. Khan, I.T.; Nadeem, M.; Imran, M.; Ullah, R.; Ajmal, M.; Jaspal, M.H. Antioxidant properties of Milk and dairy products: A comprehensive review of the current knowledge. Lipids Health Dis. 2019, 18, 41. [CrossRef]

82. Drugs and Lactation Database (LactMed) [Internet]. Bethesda (MD): National Library of Medicine (US); 2006 Vitamin C. Available online: https: / /www.ncbi.nlm.nih.gov/books/NBK544628/ (accessed on 20 July 2020).

83. Tsopmo, A. Phytochemicals in human milk and their potential antioxidative protection. Antioxidants 2018, 7, 32. [CrossRef]

84. Vishwanathan, R.; Kuchan, M.J.; Sen, S.; Johnson, E.J. Lutein and preterm infants with decreased concentrations of brain carotenoids. J. Pediatr. Gastroenterol. Nutr. 2014, 59, 659-665. [CrossRef] [PubMed]

85. Zielinska, M.A.; Hamulka, J.; Grabowicz-Chadrzyńska, I.; Bryś, J.; Wesolowska, A. Association between breastmilk LC PUFA, carotenoids and psychomotor development of exclusively breastfed infants. Int. J. Environ. Res. Public Health 2019, 16, 1144. [CrossRef] [PubMed] 
86. Padilha, M.; Danneskiold-Samsøe, N.B.; Brejnrod, A.; Hoffmann, C.; Cabral, V.P.; de Iaucci, J.M.; Sales, C.H.; Fisberg, R.M.; Cortez, R.V.; Brix, S.; et al. The human milk microbiota is modulated by maternal diet. Microorganisms 2019, 7, 502. [CrossRef] [PubMed]

87. Le Doare, K.; Holder, B.; Bassett, A.; Pannaraj, P.S. Mother's Milk: A purposeful contribution to the development of the infant microbiota and immunity. Front. Immunol. 2018, 9, 1. [CrossRef] [PubMed]

88. Fernández, L.; Langa, S.; Martín, V.; Maldonado, A.; Jiménez, E.; Martín, R.; Rodríguez, J.M. The human milk microbiota: Origin and potential roles in health and disease. Pharmacol. Res. 2013, 69, 1-10. [CrossRef]

89. Gomez-Gallego, C.; Garcia-Mantrana, I.; Salminen, S.; Collado, M.C. The human milk microbiome and factors influencing its composition and activity. Semin. Fetal Neonatal Med. 2016, 21, 400-405. [CrossRef]

90. Dreyer, J.L.; Liebl, A.L. Early colonization of the gut microbiome and its relationship with obesity. Hum. Microbiome J. 2018, 10, 1-5. [CrossRef]

91. Leghi, G.E.; Netting, M.J.; Middleton, P.F.; Wlodek, M.E.; Geddes, D.T.; Muhlhausler, B.S. The impact of maternal obesity on human milk macronutrient composition: A systematic review and meta-analysis. Nutrients 2020, 12, 934. [CrossRef]

92. Chong, C.Y.L.; Bloomfield, F.H.; O'Sullivan, J.M. Factors affecting gastrointestinal microbiome development in neonates. Nutrients 2018, 10, 274. [CrossRef]

93. Fitzstevens, J.L.; Smith, K.C.; Hagadorn, J.I.; Caimano, M.J.; Matson, A.P.; Brownell, E.A. Systematic review of the human milk microbiota. Nutr. Clin. Pract. 2017, 32, 354-364. [CrossRef] [PubMed]

94. Ho, N.T.; Li, F.; Lee-Sarwar, K.A.; Tun, H.M.; Brown, B.P.; Pannaraj, P.S.; Bender, J.M.; Azad, M.B.; Thompson, A.L.; Weiss, S.T.; et al. Meta-analysis of effects of exclusive breastfeeding on infant gut microbiota across populations. Nat. Commun. 2018, 9, 1-13. [CrossRef] [PubMed]

95. Jennewein, M.F.; Abu-Raya, B.; Jiang, Y.; Alter, G.; Marchant, A. Transfer of maternal immunity and programming of the newborn immune system. Semin. Immunopathol. 2017, 39, 605-613. [CrossRef] [PubMed]

96. Kim, S.Y.; Yi, D.Y. Components of human breast milk: From macronutrient to microbiome and microRNA. Clin. Exp. Pediatr. 2020, 63, 301-309. [CrossRef] [PubMed]

97. Van Den Elsen, L.W.J.; Rekima, A.; Verhasselt, V. Early-Life Nutrition and Gut Immune Development. Nestle Nutr. Inst. Workshop Ser. 2019, 90, 137-149. [CrossRef]

98. Reijneveld, S.A.; Brugman, E.; Hirasing, R.A. Infantile colics: Maternal smoking as potential risk factor. Arch. Dis. Child. 2000, 83, 302-303. [CrossRef]

99. Ekblad, M.; Korkeila, J.; Lehtonen, L. Smoking during pregnancy affects foetal brain development. Acta Paediatr. Int. J. Paediatr. 2015, 104, 12-18. [CrossRef]

100. Agostoni, C.; Marangoni, F.; Grandi, F.; Lammardo, A.M.; Giovannini, M.; Riva, E.; Galli, C. Original communication earlier smoking habits are associated with higher serum lipids and lower milk fat and polyunsaturated fatty acid content in the first 6 months of lactation. Eur. J. Clin. Nutr. 2003, 57, 1466-1472. [CrossRef]

101. Hopkinson, J.M.; Schanler, R.J.; Fraley, J.K.; Garza, C. Milk production by mothers of premature infants: Influence of cigarette smoking. Pediatrics 1992, 90, 934-938.

102. Banderali, G.; Martelli, A.; Landi, M.; Moretti, F.; Betti, F.; Radaelli, G.; Lassandro, C.; Verduci, E. Short and long term health effects of parental tobacco smoking during pregnancy and lactation: A descriptive review. J. Transl. Med. 2015, 13, 1-7. [CrossRef]

103. Harrod, C.S.; Reynolds, R.M.; Chasan-Taber, L.; Fingerlin, T.E.; Glueck, D.H.; Brinton, J.T.; Dabelea, D. Quantity and timing of maternal prenatal smoking on neonatal body composition: The healthy start study. J. Pediatrics 2014, 165, 707-712. [CrossRef] [PubMed]

104. Blatt, K.; Moore, E.; Chen, A.; Van Hook, J.; Defranco, E.A. Association of reported trimester-specific smoking cessation with fetal growth restriction. Obstet. Gynecol. 2015, 125, 1452-1459. [CrossRef] [PubMed]

105. Szlagatys-Sidorkiewicz, A.; Martysiak-Zurowska, D.; Krzykowski, G.; Zagierski, M.; Kamińska, B. Maternal smoking modulates fatty acid profile of breast milk. Acta Paediatr. Int. J. Paediatr. 2013, 102. [CrossRef] [PubMed]

106. Agostoni, C.; Galli, C.; Riva, E.; Colombo, C.; Giovannini, M.; Marangoni, F. Reduced docosahexaenoic acid synthesis may contribute to growth restriction in infants born to mothers who smoke. J. Pediatrics 2005, 147, 854-856. [CrossRef] [PubMed]

107. Pirini, F.; Guida, E.; Lawson, F.; Mancinelli, A.; Guerrero-Preston, R. Nuclear and mitochondrial DNA alterations in newborns with prenatal exposure to cigarette smoke. Int. J. Environ. Res. Public Health 2015, 12, 1135-1155. [CrossRef] [PubMed]

108. Knopik, V.S.; MaCcani, M.A.; Francazio, S.; McGeary, J.E. The epigenetics of maternal cigarette smoking during pregnancy and effects on child development. Dev. Psychopathol. 2012, 24, 1377-1390. [CrossRef]

109. Lee, K.W.K.; Richmond, R.; Hu, P.; French, L.; Shin, J.; Bourdon, C.; Reischl, E.; Waldenberger, M.; Zeilinger, S.; Gaunt, T.; et al. Prenatal exposure to maternal cigarette smoking and DNA methylation: Epigenome-wide association in a discovery sample of adolescents and replication in an independent cohort at birth through 17 years of age. Environ. Health Perspect. 2015, 123, 193-199. [CrossRef]

110. Anderson, T.M.; Lavista Ferres, J.M.; You Ren, S.; Moon, R.Y.; Goldstein, R.D.; Ramirez, J.M.; Mitchell, E.A. Maternal smoking before and during pregnancy and the risk of sudden unexpected infant death. Pediatrics 2019, 143. [CrossRef]

111. Ino, T. Maternal smoking during pregnancy and offspring obesity: Meta-analysis. Pediatrics Int. 2010, 52, 94-99. [CrossRef]

112. Oken, E.; Levitan, E.B.; Gillman, M.W. Maternal smoking during pregnancy and child overweight: Systematic review and meta-analysis. Int. J. Obes. 2008, 32, 201-210. [CrossRef] 
113. Al Mamun, A.; Lawlor, D.A.; Alati, R.; O'Callaghan, M.J.; Williams, G.M.; Najman, J.M. Does maternal smoking during pregnancy have a direct effect on future offspring obesity? Evidence from a prospective birth cohort study. Am. J. Epidemiol. 2006, 164, 317-325. [CrossRef] [PubMed]

114. Koshy, G.; Delpisheh, A.; Brabin, B.J. Dose response association of pregnancy cigarette smoke exposure, childhood stature, overweight and obesity. Eur. J. Public Health 2011, 21, 286-291. [CrossRef] [PubMed]

115. Bruin, J.E.; Gerstein, H.C.; Holloway, A.C. Long-term consequences of fetal and neonatal nicotine exposure: A critical review. Toxicol. Sci. 2010, 116, 364-374. [CrossRef] [PubMed]

116. Cheraghi, M.; Salvi, S. Environmental tobacco smoke (ETS) and respiratory health in children. Eur. J. Pediatrics 2009, 168, 897-905. [CrossRef]

117. Merritt, T.A.; Mazela, J.; Adamczak, A.; Merritt, T. The Impact of Second-Hand Tobacco Smoke Exposure on Pregnancy Outcomes, Infant Health, and the Threat of Third-Hand Smoke Exposure to Our Environment and to Our Children. Available online: https: / / pubmed.ncbi.nlm.nih.gov/23421018/ (accessed on 25 October 2020).

118. Mennella, J.A.; Yourshaw, L.M.; Morgan, L.K. Breastfeeding and smoking: Short-term effects on infant feeding and sleep. Pediatrics 2007, 120, 497-502. [CrossRef] [PubMed]

119. Vickers, M.H. Developmental programming and transgenerational transmission of obesity. Ann. Nutr. Metab. 2014, 64, 26-34. [CrossRef]

120. Vickers, M.H. Early life nutrition, epigenetics and programming of later life disease. Nutrients 2014, 6, 2165-2178. [CrossRef]

121. Reynolds, C.M.; Gray, C.; Li, M.; Segovia, S.A.; Vickers, M.H. Early life nutrition and energy balance disorders in offspring in later life. Nutrients 2015, 7, 8090-8111. [CrossRef]

122. Enstad, S.; Cheema, S.; Thomas, R.; Fichorova, R.N.; Martin, C.R.; O’Tierney-Ginn, P.; Wagner, C.L.; Sen, S. The impact of maternal obesity and breast milk inflammation on developmental programming of infant growth. Eur. J. Clin. Nutr. 2020, 1-9. [CrossRef]

123. Williams, C.B.; MacKenzie, K.C.; Gahagan, S. The effect of maternal obesity on the offspring. Clin. Obstet. Gynecol. 2014, 57, 508-515. [CrossRef]

124. Oliveira, E.; Marano, D.; Do Amaral, Y.N.D.V.; Abranches, A.; Soares, F.V.M.; Moreira, M.E.L. Overweight modifies the nutritional composition of human milk? A systematic review. Cienc. Saude Coletiva 2020, 25, 3969-3980. [CrossRef] [PubMed]

125. Saben, J.L.; Sims, C.R.; Piccolo, B.D.; Andres, A. Maternal adiposity alters the human milk metabolome: Associations between nonglucose monosaccharides and infant adiposity. Am. J. Clin. Nutr. 2020, 112, 1228-1239. [CrossRef] [PubMed]

126. Amaral, Y.; Marano, D.; Oliveira, E.; Moreira, M.E. Impact of pre-pregnancy excessive body weight on the composition of polyunsaturated fatty acids in breast milk: A systematic review. Int. J. Food Sci. Nutr. 2020, 71, 186-192. [CrossRef] [PubMed]

127. Haschke, F.; Ziegler, E.E.; Grathwohl, D. Fast growth of infants of overweight mothers: Can it be slowed down? Ann. Nutr. Metab. 2014, 64, 19-24. [CrossRef]

128. Inostroza, J.; Haschke, F.; Steenhout, P.; Grathwohl, D.; Nelson, S.E.; Ziegler, E.E. Low-protein formula slows weight gain in infants of overweight mothers. J. Pediatr. Gastroenterol. Nutr. 2014, 59, 70-77. [CrossRef]

129. Ellsworth, L.; Perng, W.; Harman, E.; Das, A.; Pennathur, S.; Gregg, B. Impact of maternal overweight and obesity on milk composition and infant growth. Matern. Child Nutr. 2020, 16. [CrossRef]

130. Yang, Z.; Huffman, S.L. Nutrition in pregnancy and early childhood and associations with obesity in developing countries. Matern. Child Nutr. 2013, 9, 105-119. [CrossRef]

131. Totzauer, M.; Luque, V.; Escribano, J.; Closa-Monasterolo, R.; Verduci, E.; ReDionigi, A.; Hoyos, J.; Langhendries, J.P.; Gruszfeld, D.; Socha, P.; et al. Effect of Lower Versus Higher Protein Content in Infant Formula Through the First Year on Body Composition from 1 to 6 Years: Follow-Up of a Randomized Clinical Trial. Obesity 2018, 26, 1203-1210. [CrossRef]

132. Mäkelä, J.; Linderborg, K.; Niinikoski, H.; Yang, B.; Lagström, H. Breast milk fatty acid composition differs between overweight and normal weight women: The STEPS Study. Eur. J. Nutr. 2013, 52, 727-735. [CrossRef]

133. Linderborg, K.M.; Kalpio, M.; Mäkelä, J.; Niinikoski, H.; Kallio, H.P.; Lagström, H. Tandem mass spectrometric analysis of human milk Triacylglycerols from normal weight and overweight mothers on different diets. Food Chem. 2014, 146, 583-590. [CrossRef]

134. Nommsen, L.A.; Lovelady, C.A.; Heinig, M.J.; Lönnerdal, B.; Dewey, K.G. Determinants of energy, protein, lipid, and lactose concentrations in human milk during the first 12 mo of lactation: The DARLING Study. Am. J. Clin. Nutr. 1991, 53, 457-465. [CrossRef] [PubMed]

135. De Luca, A.; Frasquet-Darrieux, M.; Gaud, M.-A.; Christin, P.; Boquien, C.-Y.; Millet, C.; Herviou, M.; Darmaun, D.; Robins, R.J.; Ingrand, P.; et al. Higher Leptin but Not Human Milk Macronutrient Concentration Distinguishes Normal-Weight from Obese Mothers at 1-Month Postpartum. PLoS ONE 2016, 11, e0168568. [CrossRef] [PubMed]

136. Fields, D.A.; Demerath, E.W. Relationship of insulin, glucose, leptin, IL-6 and TNF- $\alpha$ in human breast milk with infant growth and body composition. Pediatric Obes. 2012, 7, 304-312. [CrossRef] [PubMed]

137. Mazzocchi, A.; Giannì, M.L.; Morniroli, D.; Leone, L.; Roggero, P.; Agostoni, C.; De Cosmi, V.; Mosca, F. Hormones in breast milk and effect on infants' growth: A systematic review. Nutrients 2019, 11, 1845. [CrossRef]

138. Kirchberg, F.F.; Grote, V.; Gruszfeld, D.; Socha, P.; Closa-Monasterolo, R.; Escribano, J.; Verduci, E.; Mariani, B.; Langhendries, J.P.; Poncelet, P.; et al. Are all breast-fed infants equal? Clustering metabolomics data to identify predictive risk clusters for childhood obesity. J. Pediatric Gastroenterol. Nutr. 2019, 68, 408-415. [CrossRef] 
139. Samuel, T.M.; Binia, A.; de Castro, C.A.; Thakkar, S.K.; Billeaud, C.; Agosti, M.; Al-Jashi, I.; Costeira, M.J.; Marchini, G.; MartínezCosta, C.; et al. Impact of maternal characteristics on human milk oligosaccharide composition over the first 4 months of lactation in a cohort of healthy European mothers. Sci. Rep. 2019, 9. [CrossRef]

140. Craig, W.J.; Mangels, A.R. Position of the American Dietetic Association: Vegetarian diets. J. Am. Diet. Assoc. 2009, 109, $1266-1282$. [CrossRef]

141. Melina, V.; Craig, W.; Levin, S. Position of the Academy of Nutrition and Dietetics: Vegetarian Diets. J. Acad. Nutr. Diet. 2016, 116, 1970-1980. [CrossRef]

142. Vegan Diets: Review of Nutritional and Health Benefits and Risks. 2018. Available online: https://www.blv.admin.ch/blv/en/ home/das-blv/organisation/kommissionen/eek/vor-und-nachteile-vegane-ernaehrung.html (accessed on 14 January 2021).

143. Richter, M.; Boeing, H.; Grünewald-Funk, D.; Heseker, H.; Kroke, A.; Leschik-Bonnet, E.; Oberritter, H.; Strohm, D.; Watzl, B. Vegan Diet Position of the German Nutrition Society (DGE). Ernaehrungs Umschau Int. 2016, 4. [CrossRef]

144. Fewtrell, M.; Bronsky, J.; Campoy, C.; Domellöf, M.; Embleton, N.; Mis, N.F.; Hojsak, I.; Hulst, J.M.; Indrio, F.; Lapillonne, A.; et al. Complementary feeding: A position paper by the European Society for Paediatric Gastroenterology, Hepatology, and Nutrition (ESPGHAN) committee on nutrition. J. Pediatric Gastroenterol. Nutr. 2017, 64, 119-132. [CrossRef]

145. Van Winckel, M.; Vande Velde, S.; De Bruyne, R.; Van Biervliet, S. Clinical practice: Vegetarian infant and child nutrition. Eur. J. Pediatrics 2011, 170, 1489-1494. [CrossRef] [PubMed]

146. Weaver, G.; Bertino, E.; Gebauer, C.; Grovslien, A.; Mileusnic-Milenovic, R.; Arslanoglu, S.; Barnett, D.; Boquien, C.Y.; Buffin, R.; Gaya, A.; et al. Recommendations for the establishment and operation of Human Milk Banks in Europe: A consensus statement from the European Milk Bank Association (EMBA). Front. Pediatrics 2019, 7. [CrossRef] [PubMed]

147. Sebastiani, G.; Barbero, A.H.; Borrás-Novel, C.; Casanova, M.A.; Aldecoa-Bilbao, V.; Andreu-Fernández, V.; Tutusaus, M.P.; Martínez, S.F.; Roig, M.D.G.; García-Algar, O. The effects of vegetarian and vegan diet during pregnancy on the health of mothers and offspring. Nutrients 2019, 11, 557. [CrossRef] [PubMed]

148. Agnoli, C.; Baroni, L.; Bertini, I.; Ciappellano, S.; Fabbri, A.; Papa, M.; Pellegrini, N.; Sbarbati, R.; Scarino, M.L.; Siani, V.; et al. Position paper on vegetarian diets from the working group of the Italian Society of Human Nutrition. Nutr. Metab. Cardiovasc. Dis. 2017, 27, 1037-1052. [CrossRef] [PubMed]

149. Karcz, K.; Królak-Olejnik, B. Vegan or vegetarian diet and breast milk composition-A systematic review. Crit. Rev. Food Sci. Nutr. 2020. [CrossRef] [PubMed]

150. Pawlak, R.; Vos, P.; Shahab-Ferdows, S.; Hampel, D.; Allen, L.H.; Perrin, M.T. Vitamin B-12 content in breast milk of vegan, vegetarian, and nonvegetarian lactating women in the United States. Am. J. Clin. Nutr. 2018, 108, 525-531. [CrossRef] [PubMed]

151. Baroni, L.; Goggi, S.; Battino, M. Planning Well-Balanced Vegetarian Diets in Infants, Children, and Adolescents: The VegPlate Junior. J. Acad. Nutr. Diet. 2019, 119, 1067-1074. [CrossRef]

152. Landrigan, P.J.; Sonawane, B.; Mattison, D.; McCally, M.; Garg, A. Chemical contaminants in breast milk and their impacts on children's health: An overview. Environ. Health Perspect. 2002, 110. [CrossRef]

153. Kim, H.; Chuvakova, T.; Kazbekova, G.; Hayward, D.; Tulenova, A.; Petreas, M.X.; Wade, T.J.; Benedict, K.; Cheng, Y.Y.; Grassman, J. Analysis of breast milk to assess exposure to chlorinated contaminants in Kazakhstan: Sources of 2,3,7,8-tetrachlorodibenzop-dioxin (TCDD) exposures in an agricultural region of southern Kazakhstan. Environ. Health Perspect. 1999, 107, $447-457$. [CrossRef]

154. van den Berg, M.; Kypke, K.; Kotz, A.; Tritscher, A.; Lee, S.Y.; Magulova, K.; Fiedler, H.; Malisch, R. WHO/UNEP global surveys of PCDDs, PCDFs, PCBs and DDTs in human milk and benefit-risk evaluation of breastfeeding. Arch. Toxicol. 2017, 91, 83-96. [CrossRef]

155. Currie, J.; Putnam, H. Early-Life Origins of Lifecycle Well-Being: Research and Policy Implications. J. Policy Anal. Manag. 2015, 34, 208-242. [CrossRef] [PubMed]

156. Lipman, T.H.; Lobo, M.L. Special Issue on Social Determinants of Health. J. Pediatr. Nurs. 2017, 37, 1-2. [CrossRef] [PubMed]

157. Gadson, A.; Akpovi, E.; Mehta, P.K. Exploring the social determinants of racial/ethnic disparities in prenatal care utilization and maternal outcome. Semin. Perinatol. 2017, 41, 308-317. [CrossRef] [PubMed]

158. Kozhimannil, K.B.; Vogelsang, C.A.; Hardeman, R.R.; Prasad, S. Disrupting the Pathways of Social Determinants of Health: Doula Support during Pregnancy and Childbirth. J. Am. Board Fam. Med. 2016, 29, 308-317. [CrossRef] [PubMed]

159. Andermann, A. Taking action on the social determinants of health in clinical practice: A framework for health professionals. CMAJ 2016, 188, E474-E483. [CrossRef] [PubMed]

160. Géa-Horta, T.; Silva, R.D.C.R.; Fiaccone, R.L.; Barreto, M.L.; Velásquez-Meléndez, G. Factors associated with nutritional outcomes in the mother-child dyad: A population-based cross-sectional study. Public Health Nutr. 2016, 19, 2725-2733. [CrossRef]

161. Temple Newhook, J.; Newhook, L.A.; Midodzi, W.K.; Murphy Goodridge, J.; Burrage, L.; Gill, N.; Halfyard, B.; Twells, L. Poverty and Breastfeeding: Comparing Determinants of Early Breastfeeding Cessation Incidence in Socioeconomically Marginalized and Privileged Populations in the FiNaL Study. Health Equity 2017, 1, 96-102. [CrossRef]

162. WHO. Protecting, Promoting, and Supporting Breastfeeding in Facilities Providing Maternity and Newborn Services: The Revised Baby-Friendly Hospital Initiative 2018; WHO: Geneva, Switzerland, 2019.

163. Bzikowska-Jura, A.; Czerwonogrodzka-Senczyna, A.; Olędzka, G.; Szostak-Węgierek, D.; Weker, H.; Wesołowska, A. Maternal nutrition and body composition during breastfeeding: Association with human milk composition. Nutrients 2018, 10, 1379. [CrossRef] 